American Journal of Infectious Diseases 5 (2): 112-117, 2009

ISSN 1553-6203

(C) 2009 Science Publications

\title{
Isolation and Characterization of Potential Probiotic Escherichia coli Strains from Rat Faecal Samples
}

\author{
${ }^{1}$ Prasant Kumar, ${ }^{1}$ S. Ferzin, ${ }^{2}$ S. Chintan and ${ }^{1}$ G. Naresh Kumar \\ ${ }^{1}$ Molecular Microbial Biochemistry Laboratory, Department of Biochemistry, \\ Faculty of Science, Maharaja Sayajirao University of Baroda, Vadodara-390002, Gujarat, India \\ ${ }^{2}$ BRD School of Biosciences, Sardar Patel University, Vallabh Vidyanagar, Gujarat, India
}

\begin{abstract}
Problem statement: Gastrointestinal disorders mainly diarrhea is the most common cause of morbidity and mortality among infants and children in the developing countries occurs due to infection by enteropathogens. Ccontrol of these pathogens could be achieved by nonpathogenic Escherichia coli producing bacteriocins. Approach: Primary aim of this study was to isolate E. coli strains which inhibit enteropathogens. For this purpose, E. coli strains were isolated and tested for probiotic properties such as antimicrobial activity against enteropathogens, antibiotic susceptibility and resistance to low $\mathrm{pH}$, absence of virulence traits, susceptibility to proteolytic activity and detection of colicins type. Results: Approximately 280 E. coli strains were collected from rat feacal samples at different ages and were screened for their antimicrobial activity. Out of these, 47 isolates showed antimicrobial effect against E. coli DH5 $\alpha$ and BL21 strains and 16 were effective against different pathogens viz. Salmonella sp., Klebisella pneumoniae, Staphylococcus aureus and Enterobacter sp. These 16 isolates were susceptible to the common Antibiotics and most of them better survived at $\mathrm{pH} 3$ and a few survived even at $\mathrm{pH} 2$. Colony PCR of these isolates with colicinogenic primer demonstrated the presence of multiple colicin types. Out of 16 isolates, 12 had multiple pore forming colicins of E1 and $1 \mathrm{a} / 1 \mathrm{~b}$ type. In addition to the pore forming $\mathrm{E} 1$ and $1 \mathrm{a} / 1 \mathrm{~b}$ colicins, four $E$. coli strains $16,2 \mathrm{P}$ and 14, 20 had Emix (nuclease type)/BD type (translation blocker) colicins, respectively. Conclusion: This study showed that $E$. coli isolates 10,14 and $14 \mathrm{P}$ possess good probiotic properties and could be effective against enteropathogens.
\end{abstract}

Key words: Probiotic, Escherichia coli, Colicins

\section{INTRODUCTION}

The gastrointestinal tract is a biologically diverse and complicated system which contains around $10^{14}$ bacterial cells and up to 1000 species ${ }^{[1]}$. The dominant microflora in faecal samples is obligatory anaerobic (Bacteroides spp., Eubacterium spp., Bifidobacterium spp., Lactobacilli) and anaerobic (Cocci and Clostridium spp.). In addition, facultative anaerobic organisms such as Escherichia coli, Enterococci and Streptococci are also present ${ }^{[2]}$. The microbial population consists of commensurate bacteria and opportunistic pathogens. Some of the commensurate bacteria with beneficial effects to the host have been employed as probiotics.

Probiotics are live microorganisms which when administered in adequate amount confer health benefits to the host. The major groups are Lactobacilli, Bifidobacteria and some minor groups are
Saccharomyces, Streptococcus, E. coli Nissle 1917 and E. coli $\mathrm{H} 22$ strains have been reported as potential therapeutic agents ${ }^{[3]}$. Probiotic bacteria possess the ability to survive in the host depending on their metabolic activity, resistant to gastric acidity, adhesion to the mucosal surface, friendly to the host and protect the host against infection ${ }^{[4]}$. Antimicrobial substances include short chain fatty acid, hydrogen peroxide and bacteriocins. Bacteriocins relatively narrow killing spectrum and are only toxic to bacteria closely related to the producing strain ${ }^{[5]}$. According to Klaenhammer, 99\% of all bacteria may make at least one bacteriocin ${ }^{[4,6]}$. Mode of action of bacteriocin produced from gram positive and gram negative microorganism differ and the immune responses activation in host against gram positive and gram negative also vary ${ }^{[3,7]}$. Consortium of organisms might be more effective than the application of a single strain.

Corresponding Author: G. Naresh Kumar, Molecular Microbial Biochemistry Laboratory, Department of Biochemistry, Faculty of Science, Maharaja Sayajirao University of Baroda, Vadodara-390002, Gujarat, India Tel: +91-265-2795594 Fax: +91-265-279 
Probiotics were mainly Lactobacillus and Bifidobacteria, however enteric Escherichia coli isolates were relatively less investigated. A nonpathogenic strain has been well established in human medicine since $1917^{[8]}$. This strain was used successfully under the brand name Mutaflor for treating various gut-related diseases, e.g., chronic constipation, ulcerative colitis, Crohn's disease, or pouchitis. In addition, the strain prevented colonization of the intestine with microbial pathogens in new born infants $^{[8]}$. In Germany, E. coli strain Nissle 1917 is authorized under the brand name Ponsocol for the prophylaxis of neonatal calf diarrhea and has been marketed since 2001. E. coli H22 produces several antimicrobial compounds with inhibitory capabilities against pathogenic Enterobacter spp. and inhibited the gastrointestinal enteric infections ${ }^{[9]}$. Bacteriocins inhibit pathogens within the closely related species such as Salmonella, Shigella, Klebsiella, Enterobacter and pathogenic E. coli, which are the most common cause of gastrointestinal illnesses. We report the isolation of potential probiotic of $E$. coli strains from rat faecal matter which could eliminate gram negative pathogens.

\section{MATERIALS AND METHODS}

Isolation of Escherichia coli from Rats faecal samples: Faecal samples were collected from Charles Foster rats of different age groups. Samples were dissolved in $10 \mathrm{~mL}$ of $0.85 \% \mathrm{NaCl}$ and agitated vigorously. Serial dilutions of the resulting suspensions were spread on MacConkey lactose agar (Himedia Laboratories) and incubated for $24 \mathrm{~h}$ at $37^{\circ} \mathrm{C}$. Approx 10-15 lactose-positive colonies from each sample were selected to perform IMViC tests. Isolates confirmed IMViC positives were finally transferred to HiCrome ${ }^{\mathrm{TM}}$ Coliform Agar (HiMedia Laboratories). Isolated strains confirmed by above tests as E. coli were used to screen for their probiotic ability.

Testing for Antimicrobial activity: For detection of antimicrobial activity, agar spot tests were performed $^{[10]}$. Indicator strains were grown in Luria broth at $37^{\circ} \mathrm{C}$ and approximately $5 \times 10^{7}$ cells were inoculated into $4 \mathrm{~mL}$ of soft agar containing $0.7 \%$ agar) and poured over the plate on which the producer was spotted. The plates were incubated at $37^{\circ} \mathrm{C}$ for $24 \mathrm{~h}$. Inhibitory activity was demonstrated by a clear zone around the spots.

Testing for resistance to antibiotics: $E$. coli strains were examined for resistance to amikacin $(30 \mu \mathrm{g})$, amoxyclav $(30 \mu \mathrm{g})$, ampicillin $(10 \mu \mathrm{g})$, ceftazidime
(30 $\mu \mathrm{g})$, cephotaxime $(30 \mu \mathrm{g})$, co-trimoxazole $(25 \mu \mathrm{g})$, ciprofloxacin $(5 \mu \mathrm{g})$, cefuroxime $(30 \mu \mathrm{g})$, furazolidone $(100 \mu \mathrm{g})$, gentamicin $(10 \mu \mathrm{g})$, nitrofurantoin $(300 \mu \mathrm{g})$, nalidixic acid $(30 \mu \mathrm{g})$, netilin $(30 \mu \mathrm{g})$, ofloxacin $(10 \mu \mathrm{g})$ and tetracycline $(30 \mu \mathrm{g})$ and tobramycin $(10 \mu \mathrm{g})$ using commercial discs (HiMedia Laboratories). E. coli strain BL21 sensitive to all the antibiotics was included for quality control. Characterization of strains as susceptible, resistant or having reduced susceptibility was done in accordance with the manufacturer's instructions on sizes of inhibition zones around each disc, which matched the interpretive criteria recommended by the Clinical and Laboratory Standards Institute (CLSI).

Tolerance to acidic $\mathbf{p H}$ values: $E$. coli strains were grown in Luria broth (HiMedia) at $37^{\circ} \mathrm{C}$ overnight, subcultured into fresh Luria broth and incubated till the culture was grown up to $0.6 \mathrm{OD}$ at $550 \mathrm{~nm}$. The cultures were centrifuged at $5000 \times \mathrm{g}$ for $10 \mathrm{~min}$. The pellets were washed in sterile Phosphate-Buffered Saline (PBS) pH 7 and resuspended in PBS. Initial count was determined with appropriate dilution. Each strain was diluted 1/100 in PBS at pH 1, 2 and 3. Incubation times were 2, 4 and $6 \mathrm{~h}$. Bacterial cultures were then transferred to Luria agar plates and incubated at $37^{\circ} \mathrm{C}$ overnight $^{[11,12]}$. The number of colonies was counted to obtain the viable counts at each time interval. Survival percentage of strains to different $\mathrm{pH}$ values was then calculated as percentage survival $=($ viable counts after acid exposure/initial viable counts $) \times 100^{[10]}$.

Detection of pathogenic strains: Pathogenic detection of $E$. coli isolates was done by using eight primers as reported by Toma et al. ${ }^{[13]}$.

Characterization of the antimicrobial agent: Samples of culture supernatants, pellets and crude extract were examined for susceptibility to proteolytic enzymes. The following enzymes were used: Proteinase $\mathrm{K}\left(5 \mathrm{mg} \mathrm{mL}^{-1}\right)$ and Trypsin $\left(2 \mathrm{mg} \mathrm{mL}^{-1}\right)^{[12]}$. The crude extract was treated with enzymatic solutions and incubated at $37^{\circ} \mathrm{C}$ for $1 \mathrm{~h}$, after which the remaining activity was determined by the agar spot technique ${ }^{[10]}$.

Detection and identification of Colicin: Culture was grown overnight and freshly inoculated $50 \mu \mathrm{L}$ in $5 \mathrm{~mL}$ in Minimal media containing $0.6 \%$ casamino acid and $1 \%$ glucose and grown till 0.6 OD. This culture was split into two parts and one part was induced with Mitomycin C (200 ng mL $\left.\mathrm{m}^{-1}\right)$. After $4 \mathrm{~h}$ of incubation at $37^{\circ} \mathrm{C}$ (for induced culture), the samples were centrifuged at $15000 \mathrm{~g} / 10 \mathrm{~min} / 4^{\circ} \mathrm{C}$. Supernatant was filtered with 
cellulose acetate filter $(0.2 \mu \mathrm{m}$ filter $)$ and $5 \mu \mathrm{L}$ was spotted on the indicator organism i.e., Salmonella sp., Klebisella pneumoniae, Staphylococcus aureus and Enterobacter asburiae. The pellet was suspended in $0.05 \mathrm{M}$ Phosphate buffer $\mathrm{pH} 7.0$ and sonicated 30-60 sec and centrifuged at $15000 \mathrm{~g} / 10 \mathrm{~min} / 4^{\circ} \mathrm{C}$, lysis culture was filtered with cellulose acetate filter $(0.2 \mu \mathrm{m}$ filter $)$ and $5 \mu \mathrm{L}$ was spotted on the indicator organism. PCRbased method was used for identification of 18 different colicins using nine primers ${ }^{[14]}$.

\section{RESULTS}

Isolation of $E$. coli strains from rat faecal matter: On the Hichrome coliform agar plates, rat faecal samples contained E. coli $(4.79 \pm 1.204) \times 10^{8}\left(\mathrm{Cfu} \mathrm{gm}{ }^{-1}\right.$ wet faecal samples) after weaning and $(2.32 \pm 1.021) \times 10^{6}$ (Cfu $\mathrm{gm}^{-1}$ wet faecal samples) at adults stage.

Screening of $E$. coli for antimicrobial activity: In primary screening the antimicrobial activity of pure isolates were determined by agar spot method against E. coli (DH5 $\alpha$ and BL21) on Luria agar (LA). A total of 47 of 288 isolates of $E$. coli produced zone of inhibition against E. coli DH5 $\alpha$ and BL21 strains. Secondary screening was performed by induction of 47 isolates with mitomycin C. Antimicrobial activity of the culture filtrates against the test organisms Escherichia coli, Enterobacter asburiae, Klebisella sp., Staphylococcus aureus, Salmonella typhi and Salmonella abony is shown in Table 1 and Fig. 1. Culture filtrates which showed antimicrobial activity towards pathogens were treated with proteinase $\mathrm{K}$ and protease which resulted in lost of antimicrobial effect thus suggesting that the antimicrobial compound is a protein. Sixteen out of 47 isolates showed better inhibitory activity against different pathogens.
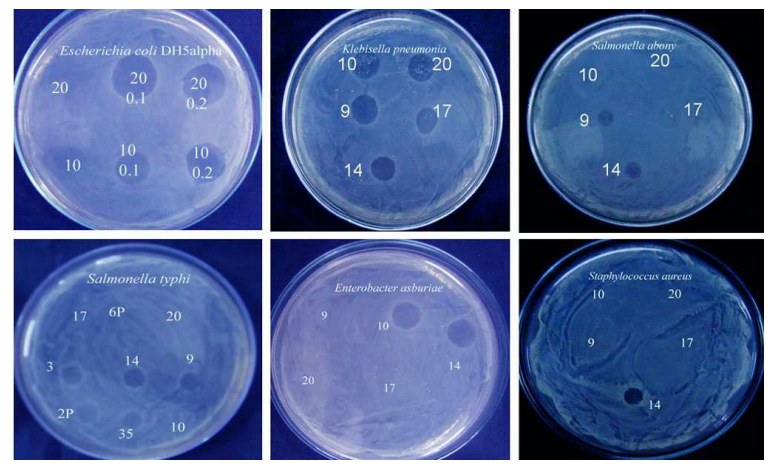

Fig. 1: Supernatant of E. coli isolates showed antimicrobial activity in the presence of mitomycin $\mathrm{C}$ induction
Antibiotic susceptibility of rat faecal $E$. coli isolates: Most isolates did not show multi-drug resistance and the isolates which showed low multiple resistance were eliminated in initial screening with commercial antibiotics (data not shown). Sixteen isolates were finally screened by using commercial antibiotics discs (HiMedia Laboratories) Table 2.

Acid tolerance assay: Acid tolerance assay was performed at different $\mathrm{pH}-1.0,2.0$ and 3.0 for the eight antibiotic sensitive strains. Isolates $E$. coli strains 10, 20 and 16 showed higher acid tolerance whereas E. coli strains $3,44,45,14$ and 17 showed poor acid tolerance at $\mathrm{pH}$ 2.0. But at $\mathrm{pH}$ 3.0, all the isolates showed good acid tolerance up to $6 \mathrm{~h}$. However, none of the isolates showed acid tolerance at pH 1.0 (Table 3).

Detection of pathogenic strains by Multiplex PCR of indicator genes: Positive controls were generated by obtaining amplicons for seven indicator genes: aggR, est, aspU, CVD432, elt, eae and stx. The sizes of the amplicons were similar to the reported pathogenic genes. Hence, the primers were used to determine the presence of the pathogenic genes in the E. coli isolates. No amplicons were obtained from the genomic DNA of all the E. coli isolates.

Table 1: Antimicrobial activity of E. coli against Enteropathogens

\begin{tabular}{ll}
\hline E. coli cultureNo. & Enteropathogens \\
\hline $10,14,14 \mathrm{P}$ & Enterobacter asburiae \\
$9,10,14,17,20,14 \mathrm{P}$ & Klebsiella pneumoniae \\
$3,9,14,35,44,2 \mathrm{P}, 8 \mathrm{P}$ & Salmonella typhi \\
$10,14,16,14 \mathrm{P}$ & Staphylococcus aureus \\
$9,14,2 \mathrm{P}, 8 \mathrm{P}$ & Salmonella abony \\
\hline
\end{tabular}

Table 2: Antibiotic susceptibility pattern of E. coli isolates (Concentration of antibiotic in $\mu \mathrm{g} \mathrm{mL}^{-1}$ )

Culture A G Ac $\mathrm{Tb}$ Co $\mathrm{Ce} \mathrm{Na} \mathrm{Nt} \mathrm{Nf}$ Ak Cf $\mathrm{Ca}$ Of $\mathrm{T} \quad \mathrm{Cu}$

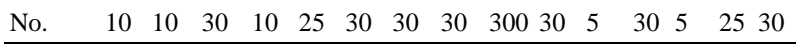

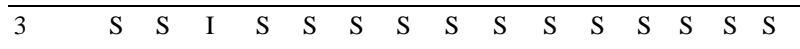

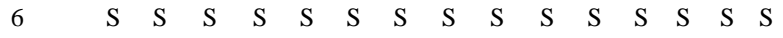

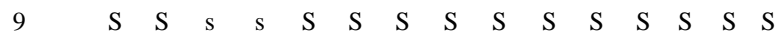

$\begin{array}{llllllllllllllll}10 & \mathrm{~S} & \mathrm{~S} & \mathrm{~S} & \mathrm{~S} & \mathrm{~S} & \mathrm{~S} & \mathrm{~S} & \mathrm{~S} & \mathrm{~S} & \mathrm{~S} & \mathrm{~S} & \mathrm{~S} & \mathrm{~S} & \mathrm{~S} & \mathrm{~S}\end{array}$

$\begin{array}{llllllllllllllll}14 & \mathrm{~S} & \mathrm{~S} & \mathrm{I} & \mathrm{S} & \mathrm{S} & \mathrm{S} & \mathrm{S} & \mathrm{S} & \mathrm{S} & \mathrm{S} & \mathrm{S} & \mathrm{S} & \mathrm{S} & \mathrm{S} & \mathrm{S}\end{array}$

$\begin{array}{llllllllllllllll}16 & \mathrm{~S} & \mathrm{~S} & \mathrm{~S} & \mathrm{~S} & \mathrm{~S} & \mathrm{~S} & \mathrm{~S} & \mathrm{~S} & \mathrm{~S} & \mathrm{~S} & \mathrm{~S} & \mathrm{~S} & \mathrm{~S} & \mathrm{~S} & \mathrm{~S}\end{array}$

$\begin{array}{llllllllllllllll}17 & \text { S } & \text { S } & \text { R } & \text { S } & \text { S } & \text { S } & \text { S } & \text { S } & \text { I } & \text { S } & \text { S } & \text { S } & \text { S } & \text { S } & \text { S }\end{array}$

$\begin{array}{llllllllllllllll}19 & \mathrm{R} & \mathrm{S} & \mathrm{I} & \mathrm{S} & \mathrm{S} & \mathrm{S} & \mathrm{S} & \mathrm{S} & \mathrm{S} & \mathrm{S} & \mathrm{S} & \mathrm{S} & \mathrm{S} & \mathrm{S} & \mathrm{S}\end{array}$

$\begin{array}{llllllllllllllll}20 & \text { S } & \text { S } & \text { I } & \text { S } & \text { S } & \text { S } & \text { S } & \text { S } & \text { I } & \text { S } & \text { S } & \text { S } & \text { S } & \text { S } & \text { S }\end{array}$

$\begin{array}{llllllllllllllll}21 & \mathrm{~S} & \mathrm{~S} & \mathrm{~S} & \mathrm{~S} & \mathrm{~S} & \mathrm{~S} & \mathrm{~S} & \mathrm{~S} & \mathrm{I} & \mathrm{S} & \mathrm{S} & \mathrm{S} & \mathrm{S} & \mathrm{S} & \mathrm{S}\end{array}$

$\begin{array}{llllllllllllllll}35 & \text { I } & \text { S } & \text { I } & \text { S } & \text { S } & \text { S } & \text { S } & \text { S } & \text { S } & \text { S } & \text { S } & \text { S } & \text { S } & \text { S } & \text { S }\end{array}$

$\begin{array}{llllllllllllllll}44 & \mathrm{~S} & \mathrm{~S} & \mathrm{I} & \mathrm{S} & \mathrm{S} & \mathrm{S} & \mathrm{S} & \mathrm{S} & \mathrm{R} & \mathrm{S} & \mathrm{S} & \mathrm{S} & \mathrm{S} & \mathrm{S} & \mathrm{S}\end{array}$

$\begin{array}{llllllllllllllll}45 & \mathrm{~S} & \mathrm{~S} & \mathrm{~S} & \mathrm{~S} & \mathrm{~S} & \mathrm{~S} & \mathrm{~S} & \mathrm{~S} & \mathrm{I} & \mathrm{S} & \mathrm{S} & \mathrm{S} & \mathrm{S} & \mathrm{S} & \mathrm{S}\end{array}$

$\begin{array}{llllllllllllllll}2 \mathrm{P} & \mathrm{S} & \mathrm{S} & \mathrm{S} & \mathrm{S} & \mathrm{S} & \mathrm{S} & \mathrm{S} & \mathrm{S} & \mathrm{S} & \mathrm{S} & \mathrm{S} & \mathrm{S} & \mathrm{S} & \mathrm{S} & \mathrm{S}\end{array}$

$\begin{array}{llllllllllllllll}8 \mathrm{P} & \mathrm{S} & \mathrm{S} & \mathrm{S} & \mathrm{S} & \mathrm{S} & \mathrm{S} & \mathrm{S} & \mathrm{S} & \mathrm{S} & \mathrm{S} & \mathrm{S} & \mathrm{S} & \mathrm{S} & \mathrm{S} & \mathrm{S}\end{array}$

$\begin{array}{llllllllllllllll}14 \mathrm{P} & \mathrm{S} & \mathrm{S} & \mathrm{S} & \mathrm{S} & \mathrm{S} & \mathrm{S} & \mathrm{S} & \mathrm{S} & \mathrm{S} & \mathrm{S} & \mathrm{S} & \mathrm{S} & \mathrm{S} & \mathrm{S} & \mathrm{S}\end{array}$ 
Am. J. Infect. Dis., 5 (2): 112-117, 2009

Table 3: Acid tolerance of E. coli isolates

\begin{tabular}{|c|c|c|c|c|c|c|c|}
\hline \multirow[b]{3}{*}{ Strain } & \multicolumn{7}{|c|}{ AT: Survival percentage $(\% \pm \mathrm{SD})$ after incubation } \\
\hline & \multirow{2}{*}{$\begin{array}{l}\mathrm{pH} 1.0 \\
2 \mathrm{~h}\end{array}$} & \multicolumn{3}{|c|}{$\mathrm{pH} 2.0$} & \multicolumn{3}{|c|}{$\mathrm{pH} 3.0$} \\
\hline & & $2 \mathrm{~h}$ & $4 \mathrm{~h}$ & $6 \mathrm{~h}$ & $2 \mathrm{~h}$ & $4 \mathrm{~h}$ & $6 \mathrm{~h}$ \\
\hline$\overline{E .}$ coli 17 & $0.00 \pm 0.00$ & $0.740 \pm 0.15$ & $0.090 \pm 0.03$ & $0.01 \pm 0.00$ & $71.95 \pm 2.47$ & $61.50 \pm 2.12$ & $39.40 \pm 3.68$ \\
\hline E. coli 14 & $0.00 \pm 0.00$ & $2.260 \pm 0.21$ & $0.600 \pm 0.14$ & $0.00 \pm 0.00$ & $35.50 \pm 4.95$ & $19.80 \pm 3.11$ & $11.95 \pm 0.92$ \\
\hline E. coli 45 & $0.00 \pm 0.00$ & $0.220 \pm 0.01$ & $0.150 \pm 0.01$ & $0.06 \pm 0.01$ & $46.50 \pm 6.36$ & $38.65 \pm 1.06$ & $35.55 \pm 0.21$ \\
\hline E. coli 44 & $0.00 \pm 0.00$ & $2.100 \pm 0.14$ & $1.180 \pm 0.03$ & $0.18 \pm 0.01$ & $67.00 \pm 5.66$ & $58.15 \pm 3.04$ & $14.80 \pm 1.13$ \\
\hline E. coli 3 & $0.00 \pm 0.00$ & $0.415 \pm 0.01$ & $0.350 \pm 0.00$ & $0.09 \pm 0.01$ & $68.25 \pm 2.52$ & $56.00 \pm 8.49$ & $43.13 \pm 1.28$ \\
\hline E. coli 10 & $0.00 \pm 0.00$ & $8.350 \pm 0.35$ & $7.350 \pm 0.21$ & $6.80 \pm 0.28$ & $74.50 \pm 4.95$ & $25.15 \pm 0.49$ & $21.40 \pm 1.41$ \\
\hline E. coli 20 & $0.00 \pm 0.00$ & $0.215 \pm 0.01$ & $0.130 \pm 0.04$ & $0.00 \pm 0.00$ & $41.75 \pm 2.76$ & $35.53 \pm 0.75$ & $31.15 \pm 1.63$ \\
\hline E. coli 16 & $0.00 \pm 0.00$ & $41.35 \pm 0.78$ & $15.70 \pm 2.40$ & $0.06 \pm 0.01$ & $76.20 \pm 1.13$ & $74.10 \pm 1.84$ & $45.20 \pm 0.85$ \\
\hline
\end{tabular}

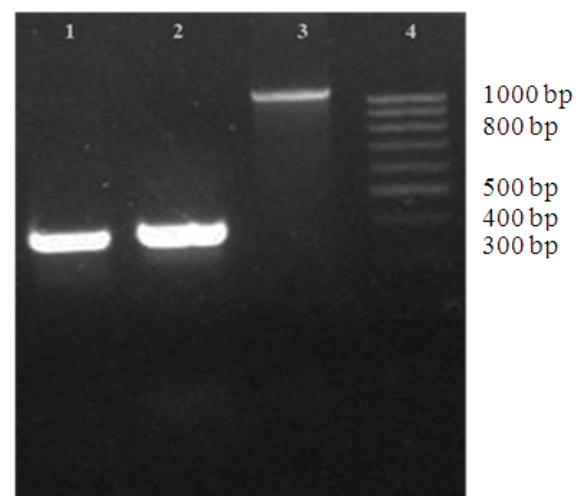

Fig. 2: 2\% Agarose gel Electrophoresis of PCR showing colicins gene (1): a/1b colicin $385 \mathrm{bp}$, (2): E1 colicin 389 bp, (3): E1 and 1a colicin combined approx $1.1 \mathrm{~kb}$, bp, (4): $100 \mathrm{bp}$ DNA ladder)

Polymerase Chain Reaction (PCR) for Identification of colicin gene in the isolates: Isolates 17 contained only E1 type; isolates 3 9, 10, 35, 44, 8P and 14P contained E1 and 1a/1b type showed in Fig. 2; isolates 16 and $2 \mathrm{P}$ contain E1, 1a/1b and Emix type; and isolates 14 and 20 contained E1, 1a/1b and B/D type colicins.

\section{DISCUSSION}

Escherichia coli count in the rat faecal matter decreased from weaning to the adult stage by about hundred fold. Variation in the abundance and diversity of microflora has been found to occur during the development of animals. In the initial stages the microflora is found to be more diverse and decrease during the transition to the adult stage ${ }^{[15]}$. In addition, the composition of the intestinal microflora is influenced by nature of the diet, antibiotic treatment and infection of exogenous opportunistic pathogens ${ }^{[16,17]}$. The results of the present study demonstrated that some of the E. coli strains (isolated of fecal samples) showed antimicrobial activity against the members of Enterobacteriaceae family viz., Enterobacter asburiae, Klebisella sp., Staphylococcus aureus, Salmonella typhi and Salmonella abony. These isolates were susceptible to the most of antibiotics tested and low resistance was observed in some cases which were eliminated in the screening. Abundance of antibiotic resistant and sensitive microorganisms found to vary in animals ${ }^{[18,19]}$. Multiplex PCR studies demonstrated that these $E$. coli strains do not contain any pathogenic traits. Antibiotic sensitivity and nonpathogenic traits are essential for probiotic organisms.

Antimicrobial activity of these $E$. coli strains was enhanced by Mitomycin C induction. Mitomycin $\mathrm{C}$ is known to induce the production of colicins ${ }^{[5]}$. Antimicrobial activity of E. coli strains 10, 14 and 14P demonstrated broad host range. Majority of the E. coli strains contained colicins $\mathrm{E} 1$ and $1 \mathrm{a} / 1 \mathrm{~b}$ in contrast to the combination of Microcin $\mathrm{H} 47$ with microcin $\mathrm{M}$ reported by Gordon at el. ${ }^{[20]}$. These colicins belong to pore forming type. Interestingly, four $E$. coli strains along with these pore forming colicins produced other colicins. Isolates 16 and $2 \mathrm{P}$ possessed $\mathrm{E}$ mix which belong to nuclease type whereas isolates 14 and 20 had B/D types which are translation blockers.

Before reaching the intestinal tract, probiotic bacteria must first survive transit through the stomach. Preliminary experiments showed that these colicin producing $E$. coli strains also had good but variable acid tolerance at $\mathrm{pH}$ 3.0. E. coli can survive at a $\mathrm{pH}$ as low as 2.0 upon induction of acid resistant genes ${ }^{[21,22]}$.

\section{CONCLUSION}

Present study demonstrates the isolation of $E$ coli strains from rat faces with effective probiotic properties. These strains have the ability to reach the small intestine and colon. In addition, most strains were susceptible to antibiotics tested, which belonged to the major classes of antibiotics used in human clinical therapy. The absence of virulence traits and antibiotic resistance can be considered a positive trait for bacteria 
used in probiotic. Some isolated strains were able to inhibit the growth of enteropathogenic bacteria and the antibacterial compounds were identified as colicins. Among strains, E. coli 10, 14 and 14P showed good probiotic properties which suggest their possible use in the therapeutic purpose against certain enteropathogens. Demonstration of their effectiveness in vivo against enteropathogens will establish their beneficial effects.

\section{REFERENCES}

1. Savage, D.C., 1977. Microbial ecology of the gastrointestinal tract. Annu. Rev. Microbial., 31: 107-133.

http://www.ncbi.nlm.nih.gov/pubmed/334036

2. Kleessen, B., E. Bezirtzoglou and J. Mättö, 2000. Culture-based knowledge on biodiversity, development and stability of human gastrointestinal microflora. Microbial Ecol. Health Dis., $\quad 12$ : 53-63. http://direct.bl.uk/bld/PlaceOrder.do?UIN=089486 270\&ETOC $=\mathrm{RN} \&$ from $=$ searchengine

3. Gillor, O., A. Etzion and M.A. Riley, 2008. The dual role of bacteriocins as anti- and probiotics. Applied Microbial. Biotechnol., 81: 591-606. http://www.ncbi.nlm.nih.gov/pubmed/18853155

4. Klaenhammer, T.R. and M.J. Kullen, 1999. Selection and design of probiotics. Int. J. Food Microbiol., 15: 45-57. http://cat.inist.fr/?aModele=afficheN\&cpsidt=1958518

5. Cascales, E., S.K. Buchanan, D. Duché, C. Kleanthous, R. Lloubès, K. Postle, M. Riley, S. Slatin and D. Cavard, 2007. Colicin biology. Microbiol. Mol. Biol. $\quad$ Rev., 71: 158-229. http://www.ncbi.nlm.nih.gov/pubmed/17347522

6. Riley, M.A. and W.E. John, 2002. Bacteriocins: Evolution, ecology and application. Annu. Rev. Microbiol., 56: 117-137. http://www.ncbi.nlm.nih.gov/pubmed/12142491

7. Otte, J.M. and D.K. Podolsky, 2004. Functional modulation of enterocytes by gram-positive and gram-negative microorganisms. Am. J. Physiol. Gastrointest. Liver Physiol., 286: 613-626. http://cat.inist.fr/?aModele=afficheN\&cpsidt=15589127

8. Buenau, R., L. Jaekel, E. Schubotz, S. Schwarz, T. Stroff and M. Krueger, 2005. Escherichia coli strain Nissle 1917: Significant reduction of neonatal calf diarrhea. J. Dairy Sci., 88: 317-323. http://www.ncbi.nlm.nih.gov/pubmed/15591395

9. Cursino, L., D. Šmajs, J. Šmarda, R.M.D. Nardi, J.R. Nicoli, E. Chartone-Souza and A.M.A. Nascimento, 2006. Exoproducts of the Escherichia coli strain $\mathrm{H} 22$ inhibiting some enteric pathogens both in vitro and in vivo. Applied Environ. Microbiol., 100: 821-829. http://www.ncbi.nlm.nih.gov/pubmed/16553738
10. Schillinger, U. and F. Lücke, 1989. Antibacterial activity of Lactobacillus sake isolated from meat. Applied Environ. Microbiol., 55: 1901-1906. http://www.ncbi.nlm.nih.gov/pubmed/2782870

11. Dunne, C., L. O’Mahony, L. Murphy, G. Thornton, D. Morrissey, S. O'Halloran, M. Feeney, S. Flynn, G. Fitzgerald, C.D.B. Kiely, G.C. O'Sullivan, F. Shanahan and J.K. Collins, 2001. In vitro selection criteria for probiotic bacteria of human origin: Correlation with in vivo findings. Am. J. Clin. Nutr., 73: 386-392. http://www.ncbi.nlm.nih.gov/pubmed/11157346

12. Mourad, K. and K. Nour-Eddine, 2006. In vitro preselection criteria for probiotic Lactobacillus plantarum strains of fermented olives origin. Int. J. Probiot. $\quad$ Prebiot., 1: 27-32. http://www.newcenturyhealthpublishers.com/probi otics_and_prebiotics/about/pdf/27-32.pdf

13. Toma, C., Y. Lu, N. Higa, N. Nakasone, I. Chinen, A. Baschkier, M. Rivas and M. Iwanaga1, 2003. Multiplex PCR assay for identification of human diarrheagenic Escherichia coli. J. Clin. Microbiol., 41: 2669-2671. http://cat.inist.fr/?aModele $=$ afficheN\&cpsidt $=1488$ 3241

14. Setia, A. and D.O. Krause, 2008. E. coli: Probiotic for Piglet Diarrhoea: Escherichia coli K88+Post Weaning Diarrhoea. VDM Verlag Publishers, ISBN: 10: 3639026276, pp: 116.

15. Inoue, R., T. Tsukahara, N. Nakanishi and K. Ushida1, 2005. Development of the intestinal microbiota in the piglet. J. Gen. Applied Microbiol., 51: 257-265. http://www.ncbi.nlm.nih.gov/pubmed/16205033

16. Jernberg, C., A. Sullivan, C. Edlund and K. Janet, 2005. Monitoring of antibiotic-induced alterations in the human intestinal microflora and detection of probiotic strains by use of terminal restriction fragment length polymorphism. Applied Environ. Microbiol., $\quad 71$ : 501-506. DOI: 10.1128/AEM.71.1.501-506.2005

17. Gostner1, A., M. Blaut, V. Scha"ffer1, G. Kozianowski and S. Theis et al., 2006. Effect of isomalt consumption on faecal microflora and colonic metabolism in healthy volunteers. Br. J. Nutr., 95: 40-50. http://www.ncbi.nlm.nih.gov/pubmed/16441915

18. Schierack, P., A.J. Jores, H. Kaspar, S. Guenther, M. Filter, J. Eichberg and L.H. Wieler, 2009. Isolation and characterization of intestinal Escherichia coli clones from wild boars in Germany. Applied Environ. Microbiol., 75: 695-702. DOI: 10.1128/AEM.01650-08 
19. Mubita, C., M. S. Lima, C. Chisenga, M. Munyeme and M. Bwalya et al., 2008. Antibiograms of faecal Escherichia coli and Enterococci species isolated from pastoralist cattle in the interface areas of the kafue basin in Zambia. Vet. Arh., 78: 179-185. http://en.scientificcommons.org/34730474

20. Gordon, D.M. and C.L. O'Brien, 2006. Bacteriocin diversity and the frequency of multiple bacteriocin production in Escherichia coli. Microbiology, 152: 3239-3244.

http://www.ncbi.nlm.nih.gov/pubmed/17074895
21. Lin, J., M.P. Smith, K.C. Chapin, H.S. Baik, G.N. Bennett and J.W. Foster, 1996. Mechanisms of acid resistance in enterohemorrhagic Escherichia coli. Applied Environ. Microbiol., 62: 3094-3100. http://aem.asm.org/cgi/content/abstract/62/9/3094

22. Hersh, B.M., F.T. Farooq, D.N. Barstad, D.L. Blankenhorn and J. L. Slonczewski, 1996. A glutamate-dependent acid resistance gene in Escherichia coli. J. Bacteriol., 178: 3978-3981. http://www.ncbi.nlm.nih.gov/pubmed/8682809 